\title{
COMMENT
}

\section{MULTI-VENUE AND THE OBSCENITY STATUTES}

The past century has witnessed a tremendous increase in the volume of criminal prosecutions initiated in the federal courts, and in the character and range of prosecutions as well. As indicated by Professor Schwartz, early federal criminal legislation was primarily "self-defensive"-i.e., it was concerned with protecting peculiarly federal functions. ${ }^{1}$ Typical were statutes aimed at the punishment of revenue frauds and of direct interference with federal courts and justice through bribery and perjury. Only after the Civil War "did the federal criminal law make its first substantial ventures beyond the punishment of acts directly injurious to the central government." 2 This was in the form of two Reconstruction enactments:

In the Civil Rights legislation individuals were protected, under certain circumstances creating federal jurisdiction, against assault, murder, and threats. The Post Office Code of 1872 afforded the protection of federal criminal law against moral corruption and financial depredation, upon a showing that postal facilities had been used to promote fraud or lotteries, or to disseminate obscenity. ${ }^{3}$

This trend toward expanding federal criminal jurisdiction has continued down to the present, buttressed most often not by explicit grants of power by the Constitution, but rather by the power of Congress "to make all Laws which shall be necessary and proper for carrying into Execution" " those powers directly conferred by the Constitution.

Since expansion of federal jurisdiction frequently is employed as a way of reaching criminal behavior with which individual states are unable to cope effectively, a very large number of federal prosecutions involve crimes with multiple state contacts. ${ }^{5}$ The problem of laying and justifying venue in such cases has been severe and recurring.

The basic constitutional requirements as to venue are set down in two separate provisions. Article III, section 2, clause 3 provides:

1 Schwartz, Federal Criminal Jurisdiction and Prosecutors' Discretion, $13 \mathrm{LAw}$ \& Contentr. Prob. 64, 65 (1948).

2 Ibid.

3 Ibid.

4 U.S. Const. art. I, §8.

6 Abrams, Conspiracy and Multi-Venue in Federal Criminal Prosecutions: The Crime Committed Formula, 9 U.C.L.A.L. REv. 751, 752 (1962) [hereinafter cited as Abrams]. 
The Trial of all Crimes, except in Cases of Impeachment, shall be by Jury; and such Trial shall be held in the State where the said Crimes shall have been committed; but when not committed within any State, the Trial shall be at such Place or Places as the Congress may by Law have directed.

Additionally, the sixth amendment states that "in all criminal prosecutions the accused shall enjoy the right to a speedy and public trial by an impartial jury of the State and district wherein the crime shall have been committed, which district shall have been previously ascertained by law . . . ." Article III may be viewed as a true criminal venue provision, setting as the proper place of trial the state in which the crime was committed. ${ }^{6}$ It "is undoubtedly a limit on the power of Congress to define the place within which a crime shall be deemed to have been committed," " at least where the crime in question has clearly been committed in only a single state or federal district. If the crime, however, proves to have contacts with more than one state or district, then the venue protection of the Constitution, under the impact of restrictive judicial interpretation of what the Constitution requires. may become essentially illusory. As the Supreme Court has stated, under article III and the sixth amendment, "the venue of trial is thereby predetermined, but those provisions do not furnish guidance for the determination of the place of the crime." 8 Therefore, in establishing the proper place of prosecution, Congress constitutionally may provide that a crime committed partly in one state and partly in another may be tried in either, and that a so-called continuing offense may be tried in any state in which any part of the offense has occurred. Congress

6 Orfield, Veme of Federal Criminal Cases, 17 U. Prtr. L. Rev. 375, 379 (1956).

The sixth amendment is, strictly speaking, a vicinage rather than a venue provision, since it merely denotes the place from which a jury in a criminal trial will be drawn. Nevertheless, the amendment is often construed as guaranteeing a trial in the district and carries the effect of a venue provision for "if the defendant asserts nis constitutional right to a trial by jury of the vicinage, he may not be tried in any district other than that in which the crime was committed since only there can such a jury be impaneled." Id. at 380 . With respect to the sixth amendment, then, the right to be tried in the vicinage may be viewed as secondary and incidental to the primary right to trial by a jury of the vicinage. Comment, 46 Mrcr. L. Rev. 964 (1948).

These general constitutional provisions are in turn implemented by Rule 18 of the Federal Rules of Criminal Procedure, which echoes the "crime committed" language of the Constitution, providing:

Except as otherwise permitted by statute or by these rules, the prosecution shall be had in a district in which the offense was committed. The court shall fix the place of trial within the district with due regard to the convenience of the defendant and the witnesses.

The exception referred to in the first sentence of the rule is meant to provide for those crimes not committed within any state (such as crimes upon the high seas), and for change of venue when allowed by Rule 21 . See text accompanying note 96 infra.

7 Rottschaefer, American Constitutional Law 728 (1939).

8 Johnston v. United States, 351 U.S. 215, 220 (1956). 
has taken advantage of such judicial interpretations by legislating a large number of offenses which may be deemed "continuing" or "multivenue" by virtue of being denoted by what one writer has called a "movement verb" - i.e., a verb which can be subjected to a "continuing" interpretation." Illustrative of the many statutory verbs which have been interpreted as implying a continuing offense are "transport," 10 "use" 11 and "remain." 12 The result of such an approach has been to create, as will be shown later in this Comment, ${ }^{13}$ apparent inconsistencies and confusion in the decided cases. Thus, Dobie, in his famous caveat, instructs the practitioner:

All federal crimes are statutory, and these crimes are often defined, hidden away amid pompous verbosity in terms of a single verb. That essential verb usually contains the key to the . . question: In what district was the crime committed? . . . . When as is so often the case, the statute enumerates several such verbs, only scrupulous, even meticulous, nicety in exact quotation can prevent these statutes, as well as the decisions under them, from proving a snare and a delusion to the unwary. ${ }^{14}$

The effect of construing the constitutional provisions so as to allow for continuing offenses has been to confer upon Congress a relatively broad power, within the limits imposed by the constitutional requirements, to determine the venue of multi-district crimes by designating the locality of the crime. Congress has exercised this power by enacting 18 U.S.C. $\$ 3237$ (1964), a general venue statute intended to be broadly applicable to multi-district and continuing offenses. This statute provides:

Except as otherwise expressly provided by enactment of Congress, any offense against the United States begun in one district and completed in another, or committed in more than one district, may be inquired of and prosecuted in any district in which such offense was begun, continued, or completed.

Any offense involving the use of the mails, or transportation in interstate or foreign commerce, is a continuing

9 Abrams 791.

10 Armour Packing Co. v. United States, 209 U.S. 56, 72 (1908) (interpreting the Elkins Act, 32 Stat. 847 (1903), 49 U.S.C. $\$ \$ 41-43$ (1964)).

11 United States v. Luros, 243 F. Supp. 160, 167 (N.D. Iowa), cert. denied, 382 U.S. 956 (1965) (interpreting 18 U.S.C. \$ 1461 (1964)).

12 United States v. Cores, 356 U.S. 405 (1958) (interpreting $\$ 252$ (c) of the Immigration \& Nationality Act, 66 Stat. 220 (1952), 8 U.S.C. \$1282(c) (1964)).

13 See section II infra.

14 Dobie, Federal Jurisdiction and Procedure 511 (1928). 
offense and, except as otherwise expressly provided by enactment of Congress, may be inquired of and prosecuted in any district from, through, or into which such commerce or mail matter moves.

It will be seen that multi-venue offenses generally fall into two broad groups: (a) those crimes begun in one district and completed in another, as provided for in the first paragraph of section 3237; and (b) the so-called continuing offenses, as set down in the second paragraph of section 3237. Thus "where an essential act-element of an offense, committed in one district, can be described as continued or repeated in other districts, a court may conclude that trial may be had wherever the element is thus continued or repeated." 15

The constitutionality of the continuing or multi-venue offense concept has repeatedly been upheld by the Supreme Court. ${ }^{16}$ However, the concept, though undoubtedly constitutionally valid in many contexts, has been applied to continually widening areas of the criminal law, with little attention or critical concern being given, either by the courts or by Congress, to the underlying rationale of the concept or its appropriateness for characterizing particular kinds of criminal offenses. The courts have generally glossed over the serious constitutional venue problems raised by such a concept, concentrating upon the explicit language of applicable constitutional provisions without due regard to the underlying spirit of these provisions or to the potential abuses which the framers of the Constitution sought to prevent.

A typical instance of such indiscriminate extension of the multivenue concept by Congress occurred in 1958 in connection with the federal obscenity statutes. ${ }^{17}$ The obscenity statutes had been held con-

15 Abrams 790.

${ }^{10}$ See, e.g., United States v. Cores, 356 U.S. 405 (1958) ; Armour Packing Co. v. United States, 209 U.S. 56 (1908).

1718 U.S.C. $\$ \$ 1461-62$ (1964). Section 1461 provides in pertinent part:

Every obscene, lewd, lascivious, indecent, filthy or vile article, matter, thing, device, or substance; and-...

Every written or printed card, letter, circular, book, pamphlet, advertisement, or notice of any kind giving information, directly or indirectly, where, or how, or from whom, or by what means any of such mentioned matters, articles, or things may be obtained . . .

Is declared to be nonmailable matter and shall not be conveyed in the mails or delivered from any post office or by any letter carrier.

Whoever knowingly uses the mails for the mailing, carriage in the mails, or delivery of anything declared by this section to be nonmailable . . . or knowingly takes any such thing from the mails for the purpose of circulating or disposing thereof, or of aiding in the circulation or disposition thereof, shall be fined not more than $\$ 5,000$ or imprisoned not more than five years, or both ....

Section 1462 provides in pertinent part:

Whoever brings into the United States ... or knowingly uses any express company or other common carrier, for carriage in interstate or foreign commerce- 
stitutional prior to 1958 in Roth $v$. United States, ${ }^{18}$ on the ground that obscene matter was not constitutionally protected. However, a restrictive interpretation of venue by the Tenth Circuit in United States v. Ross ${ }^{19}$ led Congress, in 1958, to change the offense into a continuing one (essentially, by the simple expedient of substituting the verb "uses" for the verb "deposits" in the text of the statute). This drastically broadened the venue choice available to the prosecution in a case involving the mailing of obscenity by bringing the offense under the general venue provision of section 3237.

The propriety of this congressional action will soon be reviewed by the federal courts. In late 1965, two book publishers and distributors brought mandamus proceedings in the United States Court of Appeals for the District of Columbia Circuit to compel the convening of a three-judge district court for purposes of determining the constitutionality of the 1958 amendments to the federal obscenity laws. ${ }^{20}$ The court has ordered the convening of the panel, commenting that "an attack on a statute which would permit the prosecution a multiple choice of venue in this protected area of First Amendment freedoms is not patently frivolous. Such choice could induce the publisher to engage in self-censorship and thus restrict the public's access to protected publications." 21 It seems likely that the decision handed down by this panel will have serious and widespread implications for the future development of obscenity law, ${ }^{22}$ and perhaps for the entire concept of continuing offenses as well.

(a) any obscene, lewd, lascivious, or filthy book, pamphlet, motionpicture film, paper, letter, writing, print, or other matter of indecent character...

Whoever knowingly takes from such express company or other common carrier any matter or thing the carriage of which is herein made unlawful-

Shall be fined not more than $\$ 5,000$ or imprisoned not more than five years, or both ....

18354 U.S. 476 (1957).

19205 F.2d 619 (10th Cir. 1953).

20 Reed Enterprises v. Corcoran, 354 F.2d 519 (D.C. Cir. 1965).

The publishers alleged that the amendments

purport to permit the prosecution of alleged violators at either the place of mailing or at the place of delivery or at any other place through which material passes, thus allegedly authorizing arbitrary forum-picking by federal prosecutors and the institution of multiple prosecutions for identical material in districts far removed from the residences and places of business of alleged violators.

Id. at 520. The petitioners further alleged that the statutory permission for forumpicking embodied in the 1958 amendments

constitutes an unlawful interference with and abridgement and denial of the freedom of the press in violation of the First Amendment; deprives persons, including these plaintiffs, of their liberty and property without due process of law, in violation of the Fifth Amendment; and deprives persons of their rights to a fair trial in a criminal prosecution guaranteed

Ibid. by the provisions of the Sixth Amendment.

21 Id. at 522.

22 The interesting history of these statutes is set forth in PaUL \& ScHwarTz, Federal Censorship: Obscenity in the MaIl (1961). 
Mr. Justice Frankfurter stated that "questions of venue in criminal cases . . . are not merely matters of formal legal procedure. They raise deep issues of public policy in the light of which legislation must be construed." ${ }^{23}$ Never is this more true than when the question asked is: Can the continuing offense concept be extended into the sensitive area of first amendment freedoms without endangering those freedoms and the venue guarantees of article III and the sixth amendment? Answering this question in the negative, this Comment will explore the present status of the continuing and multi-venue offense concept in general and its effect on the obscenity laws in particular. This will be done in an attempt to show that, in the area of obscenity law, the trend to more liberal venue statutes and judicial interpretation of venue provisions has resulted in a serious dilution of traditional constitutional protections not only of venue but of free speech as well. However, first it is necessary to understand the functions which the constitutional provisions were intended to serve, as viewed in the context of their historical background. The Comment will, therefore, first look at the historical sources of the traditional English requirement of a jury of the vicinage, the influence which the English form of jury trial exerted on the framers of the constitutional provisions, and the events which impelled the framers to retain and deeply to imbed the vicinage requirement in our own constitutional scheme.

\section{Historical BACKGROUND}

It is generally agreed that in interpreting the sixth amendment and article III, "the scope of the right protected by these provisions is to be determined by reference to the meanings of 'jury' and 'trial by jury' affixed to them in the law of England and the states at the time of the adoption of the Constitution." 24 That it was clearly intended by the Crown that basic rights granted by the English law should follow the colonists to America can be seen as early as the Elizabethan patents to Gilbert and Raleigh in which it was essentially guaranteed that colonists would possess the same fundamental rights as were enjoyed by other Englishmen. ${ }^{25}$ Similar guarantees are to be found in the later charters. By the time of the colonization of America, these rights were undoubtedly believed by most Englishmen to include the right to a trial by jury. Thus, Story has said:

It was from very early times insisted on by our ancestors in the parent country, as the great bulwark of their civil and political liberties, and watched with an unceasing jealousy and solicitude. The right constitutes one of the fundamental

23 United States v. Johnson, 323 U.S. 273, 276 (1944).

24 ROTTSCHAEFER, op. cit. supra note 7, at 785 .

25 Heller, The Sixth Amendaent to the Constitumon 113-14 (1951) [hereinafter cited as HeLLER]. 
articles of Magna Charta . . . . When our more immediate ancestors removed to America, they brought this great privilege with them, as their birthright and inheritance, as a part of that admirable common law, which had fenced round and interposed barriers on every side against the approaches of arbitrary power. ${ }^{26}$

In attributing the source of the right to trial by jury to Magna Charta, Story was merely reflecting an historical misconception which was current during the entire colonial period and which was also to be found in Blackstone. ${ }^{27}$ However, in view of the reverence which Englishmen felt toward Magna Charta, the significance of the generally held belief that trial by jury was among the fundamental rights guaranteed by that document is far more important than the fact that this was an historical error.

It seems generally agreed today that, contrary to the colonial view, the sources of the right to trial by jury are to be found in the early ninth century in the royal prerogatives of the Frankish kings by which the king's officers would summon twelve men of the neighborhood to answer questions put to them in the king's name. ${ }^{28}$ This procedure was initially administrative in nature rather than judicial, limited in scope and concerned primarily with title to land and revenues. It was gradually extended, however, into wider areas of royal concern, eventually including inquiry into criminal activity. Thus, by the time of the Assizes of Clarendon in 1166, a system of inquisitions had been established as part of the machinery of criminal law, and by the middle of the thirteenth century the inquest, a forerunner of the present grand jury, was made a regular procedure by Henry II. The grand jury, which was drawn from the county, "could not inquire of any offense done in another county." ${ }^{29}$ Its task was by presentment to establish the prima facie guilt of the accused.

There soon developed a serious gap in available methods of proving guilt. This void, created by the abolition of the old forms of trial, ${ }^{30}$ came to be filled by the predecessor of the present jury:

262 Story, Commentaries on the Constitution of the United States 587-88 (3d ed. 1858).

274 Blackstone, Compmentaries *349.

28 See Helier 6.

294 Blackstone, Commentaries *303.

30 During the period when the early inquest was still primarily limited to administrative concerns, criminal liability was decided by recourse to battle, ordeal or compurgation (oath-helpers). Trial by battle eventually gave rise to the use of champions and compurgation to the futile pitting of oath-helper against oath-helper. These procedures were gradually perceived to be irrational and were eliminated. In 1166 , by the Assize of Clarendon, the scope of compurgation was greatly limited. Moreover, in 1215 Pope Innocent III removed religious endorsement from the ordeal, practically abolishing it as a trial device. 
a body of neighbors called in, either by express law, or by the consent of the parties to decide disputed questions of fact . . . because they were already acquainted with the facts... or if not already so acquainted with them, because they might easily acquire the necessary knowledge. ${ }^{31}$

Since the early petit jurors were primarily witnesses rather than judges, they had to be drawn from the immediate vicinity of the crime. ${ }^{32}$ The administration of criminal justice, therefore, was necessarily centered at the county level. Criminal cases had to be initiated by presentment in the county in which the crime was committed, and the king's itinerant justices, empowered by royal commissions, traveled to the counties. "The general result of this system of commissions was that a great deal of royal justice was done not by the permanent central courts, but in the counties, by commissioners sent out just for that occasion." ${ }^{33}$

This system of local criminal justice contained a broad implication which has not generally been appreciated: the result of requiring the use of local juries was concomitantly to introduce a democratic and representative quality into the administration of the criminal law. "From these beginnings as an administrative machine for extorting truth on any matter of royal concern from a reluctant countryside, the jury soon acquired a representative character." 34 Indeed, as has been indicated by Maitland, "the whole system of trial by jury in its earliest form implies representation-a person is tried by the county, by the neighbourhood ... . The voice of the jurors is the verdict of the country . . . "35 Nor from an early time was the right to a representative jury of one's peers limited to the royal court of the King's Bench. Even in the manorial courts:

[W] hen the lord's interests were not concerned or were not being actively asserted, the serf who sued or was sued in the manorial court got the same justice as that which the free man got; he got in theory the judgment, not of his lord, but of a body of doomsmen who were at least his peers. . . .

[T]rial by jury gradually forced its way into the manorial courts ... If a serf gets the verdict of his neighbours, he

31 Holdsworth, A Fistory of ENGLish Law 156 (2d-ed. 1903).

Although initially the jury of the presentment was also the jury which determined guilt, two separate juries were the rule by 1352 , and a trial juror could be challenged if he had served on the jury of presentment.

32 As witnesses, the jurors could be proceeded against for perjury (by attaint). Although trial by jury was at first purely voluntary, by 1275 the Statute of Westminster I subjected a defendant to the possibility of torture and imprisonment if he refused "to put himself upon the country."

33 Maitland, The Constitutional History of England 141 (1941).

34 Plucknet, Concise History of the Common Law 126 (2d ed. 1936).

35 MaITland, op. cit. supra note 33, at 71 . 
gets as good a "judgment of his peers" as a free man will get in the king's courts. ${ }^{36}$

The tendency to overlook the representative functions of the jury has been an unfortunate by-product of the early historical texts' concern with the witness function. It is to be admitted that such a restricted view, if accurate, would reinforce any argument that vicinage requirements are obsolete in a day when jurors no longer need bring with them to the courtroom their own knowledge of the neighborhood. But is such a view adequate to explain later English retention of trial by jury of the vicinage? Although the process by which the jury became transformed from witness to trier of facts was essentially complete by the 1400 's, the requirement of a jury of the vicinage was still viable and staunchly defended by the time of the American Revolution. Although the historical evidence is at best equivocal as to the actual reason, is it not likely that, since by the mid-1400's the jury's function had already been transformed from that of mere witness into impartial weigher of evidence, the impetus toward preserving trial by a jury of the vicinage had its source in something more fundamental than the original necessity for having a panel familiar with the facts of the offense? The possibility of mere inertia is not a convincing explanation for the retention of the vicinage requirement in the absence of any genuine need for it in an age of great social upheaval and innovation. The essential nature of the jury which would appear logically to explain the continued existence of the vicinage requirement in the English system from the Middle Ages up until the American Revolution is to be found in the representative character of the local jury. "This idea of the jury representing the public of a particular locality had enormous consequences in an age when representative institutions were rapidly developing." 37 That there was an urgent need for the existence of a representative jury becomes even more apparent when one considers how heavily criminal procedures were weighted in favor of the Crown. It was not, for example, until the 1700's that the rights to counsel and to a copy of the indictment were extended to persons accused of felonies other than treason. In such a climate of potential injustice, the only protection an ordinary man had against government arbitrariness and undue hardship was trial by jury in the vicinage.

In the American colonies, juries were impaneled from the earliest period, although the jury trial of colonial days was "not a rigid copy of its English prototype but rather the result of variegated experiences, experimentation, and adaptation." 38 Explicit provision, however, was often made for a jury of the vicinage. Thus Heller quotes chapter XXII of the Charter of Fundamental Laws of West Jersey as providing

361 Poltock \& Maitland, The History of English Law 581-82 (1895).

37 Plucknetr, op. cit. supra note 34, at 126.

38 HELLER. 15. 
in 1676 "that the Tryals of all causes civil and criminal, shall be heard and decided by the virdict or judgment of twelve honest men of the neighborhood, only to be summoned and presented by the sheriff of that division, or propriety where the fact or trespass is committed." 39 And similar provisions are found in the Fundamental Constitutions for the Province of East Jersey (1683): "[A]ll tryals shall be by twelve men, and as near as it may be, peers and equals, and of the neighborhood, and men without just exception . . ."40 In Virginia, the English requirement that the jury be drawn from the vicinage was deviated from, as many cases were required to be tried in Jamestown where a jury was selected from the court bystanders. In 1662, however, the statute of $2 \mathrm{Hen}$. 63-64 required that at least six of the jurors be from the neighborhood. ${ }^{41}$

In the 1770's, as tensions grew between England and the colonies, the Crown's attempts to deprive the rebellious colonists of trial in the vicinage led to great anger and resentment. Widespread protests greeted the Stamp Act, in which provision was made for revenue offenses to be tried in the Admiralty Courts, where jury trial was traditionally not available. On May 16, 1769, the Virginia House of Burgesses met to protest against the transporting of Massachusetts colonists to England for trial under a Parliamentary revival of an old statute, 35 Henry 8, and drew up the Virginia Resolves, asserting that "thereby the inestimable Privilege of being tried by a Jury from the Vicinage, as well as the Liberty of summoning and producing Witnesses on such Trial, will be taken away . . ." 42 The statute of 12 Geo. 3, c. 24 (1772) made indictment and trial for certain offenses proper "in any shire or county within this realm." The First Continental Congress, in protesting against this enactment in 1774, again referred to "the great and inestimable privilege of being tried by their peers of the vicinage" in accordance with the requirements of English common law, and asserted that the statute "deprives the American subject of a constitutional trial by jury of the vicinage." 43 Again, in October, 1774 , in the famous address to the Province of Quebec, the Continental Congress, setting forth the "inalienable rights" of English subjects, stated:

The next great right is that of trial by jury. This provides, that neither life, liberty nor property, can be taken from the possessor, until twelve of his unexceptionable countrymen and peers of his vicinage, who from that neighbourhood may reasonably be supposed to be acquainted with his character, and

39 Id. at 17.

$40 \mathrm{Ibid}$.

11 Id. at 20.

42 Virginia Resolves of May 16, 1769, Journals of the House of Burgesses of VIRGINIA, 1766-1769, at 214 (Kennedy ed. 1906).

43 Commager, Documents of American History 83-84 (2d ed. 1940). 
the characters of the witnesses, upon a fair trial, and full enquiry, face to face, in open Court before as many of the people as chuse to attend, shall pass their sentence upon oath against him .... ${ }^{44}$

And finally, in 1776, these continuing grievances culminated in the Declaration of Independence, in which the Crown was condemned "for transporting us beyond Seas to be tried for pretended offenses."

In view of the great sense of injustice which the colonists carried into the revolution concerning the king's attempts to restrict trial in the vicinage, it is not surprising that vicinage provisions were incorporated into many of the new state constitutions. Thus, although seven of the first fifteen states omitted express references to venue or vicinage, four required juries of "his" or "the" vicinage, vicinity or country, two required trial where the crime was committed and two in general terms expressed the importance of verifying facts where they arose. ${ }^{45}$ Blume, viewing these later constitutional provisions with reference to the colonial statements, has concluded that "vicinage," as used earlier by the colonists in their struggle with England, did not refer specifically to the neighborhood of the crime or even to the county in which the crime was alleged to have been committed but rather to transportation either beyond the seas to England or to a distant colony. "The writers of a great majority of the later constitutions, in copying these early provisions, misunderstood them and made definite that which purposely had been left indefinite." 46 Thus, he continues, "the problem of the early constitution writers was to guard against the dangers of transportation without taking from the legislatures power to regulate venue within a state." 47

Considering the diversity of state provisions and procedures, it is not surprising that the original Virginia Plan submitted to the Constitutional Convention in 1787 made no effort to embody actual details of criminal procedure. ${ }^{48}$ However, subsequent plans submitted to the Convention attempted to deal specifically with the problem. The New Jersey Plan, for instance, proposed "that no person shall be liable to be tried for any criminal offense committed within any of the United States, in any other state than that wherein the offense shall be committed . . . ."49 The essence of this suggestion, and similar suggestions of Pinckney and Hamilton, was adopted by the Committee on Detail and embodied in the draft constitution. It was amended slightly

441 Journals of tere Continental Congress 107 (1904).

45 Blume, The Place of Trial in Criminal Cases: Constitutional Vicinage and Venue, 43 MICH. L. REv. 59, 77 (1944); see HeLler 22-24.

46 Blume, supra note 45 , at 78 .

47 Ibid.

48 HELLER 24.

493 Farrand, The Records of the Federal Conventron of 1787, at 616 (rev. ed. 1937). 
by the Committee of the Whole to provide for trial by jury for offenses committed without the confines of any state. The provision was then sent to the Committee on Style, which incorporated it into the judiciary article. $^{\text {to }}$

It is interesting that at no time during this process was the provision ever subjected to extensive debate in the Convention. In the debates over ratification in the various states, however, the jury trial clause was subjected to scathing attacks and denounced as inadequate. The criticisms centered on three issues. First, opponents of the article argued that, since the appellate courts would have the power to review findings of both law and fact, the verdict of an impartial jury could be set aside with impunity. Secondly, they decried the absence of a jury trial provision for civil cases. "But the most vocal objections were aimed at the lack of a narrowly drawn vicinage requirement and of an explicit provision saving the right to challenge prospective jurors." 51 Typical of the complaints being made was that of Abraham Holmes, a delegate to the Massachusetts ratifying convention, that a defendant would not only be deprived of a sympathetic local jury, but more importantly "may by reason of the distance of his residence from the place of the trial, be incapable of making such a defense as he is, in justice, entitled to, and which he could avail himself of, if his trial was in the same county where the crime is said to have been committed." 52 In Virginia, Patrick Henry asserted that, rather "than have it so vaguely and equivocally provided for," he would have preferred to see trial by jury left out altogether: ${ }^{53}$ "Juries from the vicinage being not secured, this right is in reality sacrificed." 54 Grayson, agreeing with Henry, stated:

where the governing power possesses an unlimited control over the venue, no man's life is in safety. . . . The idea which I call a true vicinage is, that a man shall be tried by his neighbors. But the idea here is, that he may be tried in any part of the state. . . [Thus] they can hang anyone they please, by having a jury to suit their purpose. ${ }^{55}$

In responding to these attacks, Madison had suggested that the result of a narrowly drawn vicinage requirement would be to make it impossible to summon a jury in the event of a rebellion in the whole district. $^{56}$ Additionally, Pendleton in Virginia ${ }^{57}$ and Gore in Massa-

50 HELLER 25.

51 Ibid.

522 Elliot, Debates in the Several State Conventions on the Adoption of tHe Federal Constrtution 109-10 (1901) [hereinafter cited as EliLIOT].

533 ELLIOT 541.

643 EILIOT 545.

553 ELLTOT 568-69.

583 Eiliot 537.

673 ELLIOT 546. 
chusetts ${ }^{58}$ indicated that, since jurors were to be impartial weighers of evidence presented in court, knowledge of the neighborhood was no longer essential. But the article was primarily defended simply on grounds that a more detailed provision could not be drawn in view of the great diversity of state practices. ${ }^{59}$

After ratification when the first Congress was convened, Madison took the lead in attempting to secure passage of a Bill of Rights and drafted the original proposals for the first amendments. In an attempt to meet the criticisms which had been made of the generality of the jury trial provision in article III, he submitted two propositions to Congress. The first enumerated a series of safeguards for the accused which critics wanted to see in black and white but which made no reference to the jury. The second was intended to elaborate upon and ultimately replace the vague language of article III as follows:

That . . . the third clause be struck out, and in its place be inserted the clauses following, to wit:

The trial of all crimes (except in cases of impeachments, and cases arising in the land or naval forces, or the militia when on actual service, in time of war or public danger) shall be by an impartial jury of freeholders of the vicinage . . . provided that in cases of crimes committed within any county which may be in the possession of an enemy, or in which a general insurrection may prevail, the trial may by law be authorized in some other county, of the same state, as near as may be to the seat of the offense. ${ }^{60}$

Madison's proposed amendments met with some opposition in the House of Representatives. An attempt by Burke of South Carolina to replace the word "vicinage" by "district or county within which the offense was committed" was apparently voted down. But a proposal by Livermore to allow trial in the state where the offense was committed was passed. After some further minor changes in committee, the proposed amendment went to the Senate. Little is known of the action of the Senate on the jury trial provision; but that the Senate was unwilling to agree to the House version is clear from the following letter from Madison to Edmund Pendleton, discussing the variety of state vicinage provisions:

[The Senate] sent back the plan of amendments with some alterations which strike in my opinion at the most salutary articles. In many of the States juries, even in criminal cases,

582 EILIOT 112.

59 HELLER 27.

60 Frankfurter \& Corcoran, Petty Federal Offenses and the Constitutional Guaranty of Trial by Jury, 39 HARv. L. REv. 917, 972 (1926). See generally DuMiBauLd, Tye BILl of Rigets and What It Means Today 33-44 (1957). 
are taken from the State at large; in others, from districts of considerable extent; in a very few from the county alone. . . . The difficulty of uniting the minds of men accustomed to think and act differently can only be conceived by those who have witnessed it. ${ }^{61}$

The proposed amendment was then submitted to a conference committee, and again a letter from Madison to Pendleton is our sole source of information on the negotiations. ${ }^{62}$ Madison wrote regarding the Senate members of the committee:

They are equally inflexible in opposing a definition of the locality of Juries. The vicinage they contend is either too vague or too strict a term, too vague if depending on limits to be fixed by the pleasure of the law, too strict if limited to the County. It was proposed to insert after the word Juries "with the accustomed requisites," leaving the definition to be construed according to the judgment of professional men. Even this could not be obtained. The truth is that in most of the States the practice is different and hence the irreconcilable difference of ideas on the subject. . . . The Senate suppose also that the provision for vicinage in the Judiciary Bill, will sufficiently quiet the fears which called for an amendment on this point. ${ }^{63}$

The absence of complete information as to the Senate proceedings on the sixth amendment makes it impossible to trace the exact development of the vicinage clause, or to ascertain with any certainty the author of specific words. ${ }^{64}$ Clearly, Madison's proposed substitute for article III met with strong objections in the Senate. It appears that the House version was subsequently adopted as part of a compromise by which the House withdrew objection to all but one other change made by the Senate ${ }^{65}$ and only after the Conference Committee failed to reach an agreement on any alternative formulation. Where, when and by whom the proviso for an impartial jury of the State and district "wherein the crime shall have been committed," was added cannot be ascertained from the available records. The original Madison proposal, explicitly requiring a jury of the vicinage, clearly had its origins in the Virginia Bill of Rights. Thus, one article in summing up the actions of the Convention has speculated that Madison

615 Madison, The Writings of James Madison 420-21 (Hunt ed. 1910).

62 HELLER 32.

63 5 MADIson, op. cit. supra note 61, at 424. (Emphasis in original.)

64 HeLler 33.

65 Id. at 32-33; see DuMbauld, op. cit. supra note 60 , at $48-49$. 
transferred the phrase emphasizing the local character of the jury as found in his Virginia model to that article of the original Constitution which dealt with the jury problem. And Congress, pursuing with the local jury clause, as with all others, a policy of preserving unaltered the form of the original Constitution, transferred it back into the familiar clause of the Bill of Rights from whence it came, and then adopted the Sixth Amendment, in its final form, as adequately and familiarly expressive of the current conceptions of trial by jury. ${ }^{68}$

Heller has suggested that, in many of the early debates over jury trial, those who sought more narrowly defined vicinage requirements were in reality speaking in terms of venue, or at least may have failed to distinguish clearly the difference between the two concepts. But, as Heller himself has pointed out:

[I]f there is evidence to support this assertion, that the issue of vicinage has been confused by the use made of the term in Revolutionary and pre-Revolutionary days, the difficulties created by such loose usage were merely additional to the very evident disparity of opinion with reference to the proper area of vicinage. ${ }^{6 r}$

Thus, while there may have been some confusion over terminology, the basic issues involved in the dispute and the dangers the framers sought to guard against were clearly perceived. It must not be forgotten that the sixth amendment was adopted in the wake of a recent history of forced deportations to distant places for trial. In the colonial period the trial by a local jury was emotionally and outspokenly defended as a right bestowed by Magna Charta and as a free man's best protection against despotic government and the economic and physical hardship occasioned by trial far from home. Early provisions which required trial where the crime was committed would also, in an age of restricted travel and mobility, in effect decree trial at the defendant's home, or, if not at his home, at least where the defendant was physically present at the time the crime was committed. In any event, while the amendment as finally adopted must have still been too broadly worded to please many opponents of the original provision in article III, there can be no question that it considerably narrowed the place of trials more than proponents of a strong federal judiciary would have desired.

The wording of the amendment represented a compromise between the localist tendencies of those who wished to re-

66 Frankfurter \& Corcoran, supra note 60, at 975.

o7 HELLER 93. 
strict vicinage to the county and the Federalists who urged a minimum of restraint on the exercise of the judicial power of the national government. By tying the concept of vicinage to a system of judicial districts subject to Congressional determination, the First Congress passed the problem to its successors and left unsolved the conflicts of opinions which had divided its members. ${ }^{68}$

The outcry which resulted after adoption of the vague article III provision reflected the genuine concern of the time with protections for criminal defendants, and the compromise embodied in the amendment in response to that criticism must be seen as a rejection of the idea of nationwide criminal venue. That such nationwide venue would have facilitated the administration of criminal justice was probably as true in Revolutionary days as it is today. Thus,

It is doubtful whether the concern which led to the inclusion of two provisions regarding venue could have been to facilitate the prosecution of crime, by fixing trial in a place convenient for the government's witnesses. It is more likely that the framers were influenced by what Justice Frankfurter called "the unfairness and hardship to which trial in an environment alien to the accused exposes him." 68

As Professor Moore points out, ${ }^{70}$ since the framers could not have contemplated a society with the mobility and complexity of ours and the almost infinite variety of acts which have become criminal offenses, neither could they have contemplated the possibility of a defendant "committing" a crime in a place thousands of miles away from the place where the defendant was physically to be found at the time he acted. They could not have realized, therefore, that by tying the place of trial to the place where the crime was committed, they were providing Congress with a convenient foundation on which it could erect that very structure of nationwide criminal venue which they had explicitly rejected in their compromise.

\section{Development of the Multi-Venue Concept}

Lack of sensitivity to the competing values and problems which the constitutional framers faced in working out their compromise between protection of individual rights and efficient administration of justice has led later lawmakers, engaged in the process of adjusting these provisions to their own contemporary problems, to too narrow an interpretation of what the Constitution requires as adequate pro- 
tection of criminal defendants. This can be seen as early as 1867 when the concept of a single offense which could serve as the basis for venue either where begun or where completed was already clearly recognized and enacted into statutory form. ${ }^{71}$

The broadening effect on venue of such a statute can be seen in Hyde v. United States, ${ }^{72}$ one of the earliest cases in which the Supreme Court attempted to define the permissible outer limits of venue. Hyde, a resident of San Francisco, had been arrested in California and with three other defendants had been indicted in Washington, D. C., for conspiring to defraud the United States out of public land located in Oregon and California. In a five-to-four decision, the Supreme Court upheld the laying of venue in Washington on grounds that, since overt acts in furtherance of the conspiracy had been performed in Washington, the conspiracy itself had been "committed" in Washington. The result of the decision was to subject Hyde to trial in the District of Columbia, 3000 miles from his home, in a place where he personally had never been present in aid of the conspiracy (although Hyde's co-conspirators had participated in government proceedings in the District) and in spite of the fact that the overt acts allegedly committed in Washington were a relatively small part of the entire scheme. Indeed, the Court acknowledged the likelihood of hardship but pointed out that the necessity of efficient criminal law administration required that outcome. Certainly, by rejecting the argument of Mr. Justice Holmes for the dissent that conspiracy prosecutions should be brought "where the conspiracy exists in fact," "73 the majority greatly enlarged the multivenue possibilities inherent in conspiracy prosecutions.

One of the earliest decisions in which the continuing offense concept generally, and the problem of intervening district venue in particular, was faced by the Supreme Court and held constitutional was Armour Packing Co. v. United States, ${ }^{74}$ in which a shipper was indicted in Missouri (an intervening district adjacent to the district in which the shipment had originated) for violating the Elkins Act ${ }^{75}$ by securing transportation of goods in interstate commerce at below the carrier's published rate. The Supreme Court upheld the constitutionality of a special venue provision providing that venue could be laid in any intervening district "through which the transportation may have been conducted." Construing the constitutional provisions as merely requiring trial in the locality of the offense and not as requiring the physical presence of the defendant, the Court agreed that its construction could, in any particular case, work serious hardship by permitting prosecution in a place remote from the home and vicinage of the accused. This, how-

71 Act of March 2, 1867, ch. 169, §30, 14 Stat. 484.

72225 U.S. 347 (1912).

73 Id. at 390 (dissenting opinion).

74209 U.S. 56 (1908).

7532 Stat. $847^{\circ}(1903), 49$ U.S.C. $\$ \$ 41-43^{\circ}(1964)$. 
ever, was said to be an objection to the policy of the law but not to the power of Congress to pass it. Viewing the situation as arising from the development of modern transportation facilities, the Court stated that "considerations of convenience and hardship, while they may appeal to the legislative branch of the Government, will not prevent Congress from exercising its constitutional power in the management and control of interstate commerce." 78 The Court, looking at the nature of the offense involved, held:

Wherever such transporation is received, there the offense is to be deemed to have been committed. Why may this not be so? In this feature of the statute, the transportation being of the essence of the offense, when it takes place, whether in one district or another, whether at the beginning, at the end, or in the middle of the journey, it is equally and at all times committed. $^{77}$

The Court, by upholding the constitutionality of intervening district venue, made it possible for prosecutions to be brought where not even the "constructive" presence of the defendant could be argued to have been a proper basis for venue (as had been argued in the conspiracy cases).

The implications of the Armour and Hyde decisions for federal criminal venue are profound. In conspiracy prosecutions the choice of venue made available to the prosecution becomes almost unlimited. For example, since no distinction is made as to the importance of the overt act in furtherance of the conspiracy, minimal acts, equivocal and remote in themselves, may still provide a sufficient basis for venue, ${ }^{78}$ and the defendant may be deemed constructively present in districts into which he, and perhaps even his co-conspirators, have never physically intruded. Even outside the conspiracy area, under continuing offense statutes, intervening district prosecutions may be brought in areas having no particular interest in or connection with the offense in question simply by virtue of the fortuitous routing of a train or truck which could not be foreseen or controlled by the defendant. Certainly the courts have been aware of these implications and have often appeared uncomfortable in upholding the propriety of these venue provisions, avoiding their application if at all possible.

In United States $v$. Johnson, ${ }^{78}$ the defendant had allegedly violated the Federal Denture Act ${ }^{80}$ by mailing dentures from Chicago to Delaware where he was not licensed. The district court quashed the indict-

76209 U.S. at 77.

77 Id. at 74 .

78 See cases collected in Abrams 765-66.

79323 U.S. 273 (1944).

80 Federal Denture Act of 1942, 56 Stat. 1087, 18 U.S.C. § 1821 (1964). 
ment in Delaware, holding that prosecution was proper only in the place where the dentures were deposited in the mail. The Government appealed, arguing that an indictment could be brought in any place through which the dentures passed. Mr. Justice Frankfurter, speaking for the majority and citing Armour as precedent, reiterated that "Congress may constitutionally make the practices which led to the Federal Denture Act triable in any federal district through which an offending denture is transported." 81 The Court, however, would not authorize such discretion in choice of venue in the absence of a clear congressional mandate for a special venue provision similar to that enforced in Armour. The Court then construed the act as allowing prosecution only at the place of deposit and found the absence of an Armour-type provision not to be congressional oversight but to be far more rationally explained by differences between the two acts. The venue provision of the Elkins Act, the Court held, underlined the offense defined by that act, which was not the illegal sending or bringing of goods but rather their transportation in interstate commerce. "That transportation is inescapably a process, a continuing phenomenon." 82 The "bringing" or "sending" prohibited by the Denture Act, on the other hand, the Court viewed as a completed act rather than as a process. While pointing out that such a restrictive construction of the statutory language was not required by article III or the sixth amendment, the Court found it to be "more consonant with the considerations of historic experience and policy which underlie those safeguards in the Constitution regarding the trial of crimes." $83 \mathrm{Mr}$. Justice Frankfurter further stated:

By utilizing the doctrine of a continuing offense, Congress may, to be sure, provide that the locality of a crime shall extend over the whole area through which force propelled by an offender operates. . . . Plainly enough, such leeway not only opens the door to needless hardship to an accused by prosecution remote from home and from appropriate facilities for defense. It also leads to the appearance of abuses, if not to abuses, in the selection of what may be deemed a tribunal favorable to the prosecution. ${ }^{84}$

The distaste which the majority of the Johnson Court evidently felt for the continuing offense concept manifested itself in a finding that the language of the statute in question was ambiguous. This ambiguity the majority resolved in accord with what it felt to be the 
underlying spirit rather than letter of the constitutional provisions for venue-i.e., the necessity to protect the opportunity for trial in the vicinage of the defendant wherever possible. The constitutional "purposes" as the majority conceived them were, however, not perceived to be sufficiently strong to override congressional intent. Rather, the appeal to the constitutional policy would, as enunciated, only come into play as a tool of statutory interpretation upon a prior finding by the Court that the statute was unclear. That the Court was straining to find ambiguity in this particular statute is evident from the fact that four of the Justices were unable to discern any ambiguity in the statutory language and rejected in toto the majority's view that restriction of venue to the place of mailing was more consonant with the underlying spirit of the constitutional provisions. Thus Mr. Justice Reed's dissent (in which Mr. Chief Justice Stone and Justices Douglas and Rutledge joined) voiced his belief that the Court had misunderstood the purpose of the constitutional provisions: "We understand them to assure a trial in the place where the crime is committed and not to be concerned with the domicile of the criminal nor with his familiarity with the environment of the place of trial." 85

Perhaps the majority's reluctance to engrain its enunciated view of constitutional policy upon the law of criminal venue as a constitutional imperative can be explained by a feeling on the part of the Court that the requisite ambiguity could somehow be found in any case in which justice would require a restrictive view of venue possibilities. In 1948, however, Congress responded to the Johnson decision by incorporating the idea of a continuing offense directly into the first paragraph of section 3237, the general venue statute, and by adding a second paragraph in which offenses involving use of the mails or transportation in interstate commerce were expressly made continuing offenses. $^{86}$ Thus the Reviser's Note to section 3237 states that the section was completely rewritten to clarify legislative intent and that the second paragraph of the revised section was expressly added to meet the situation created by the decision of the Supreme Court in Johnson: "The revised section removes all doubt as to the venue of continuing offenses and makes unnecessary special venue provisions except in cases where Congress desires to restrict the prosecution of offenses to particular districts . . . ." 87

$85 \mathrm{Id}$. at $280-81$.

86 See pp. 401-02 supra, where the text of the statute is set out.

87 Reviser's Notes following 18 U.S.C. \$3237 (1964).

In the committee hearings and in the floor debates, it was pointed out that the bill involved a "revision" and not a mere "codification" of existing law, and the Reviser's notes were referred to as explaining the changes. But there was no discussion of the merits of $\S 3237$ or of other comparable changes.

Do drafting experts perform their duty to Congress, and does Congress perform its duty to the country, by dealing in this cavalier fashion with problems of such magnitude?

Hart \& Wechsler, The Federal Courts and the Federal System 1105 (1953). 
Even in the face of this explicit statement of congressional intent, however, the continuing offense statute was still vulnerable to restrictive judicial interpretation. In essence, the effect in some cases of the enactment of the revision to section 3237 was only to remove the old problem of statutory construction one step. Thus in 1953 in United States $v$. Ross, ${ }^{88}$ the Tenth Circuit held that "deposit" of obscene mail as prohibited by the obscenity statutes was not a continuing "use" of the mails within the meaning of section 3237. Accordingly, the court found that an indictment brought in Kansas, resulting from the mailing of obscene matter from California to Kansas, was not proper. The offense was construed as being complete when the material was deposited in the mailbox, and it was not deemed essential to the offense that the material actually be carried in the mails. ${ }^{89}$ Congress once more responded to a restrictive judicial interpretation of the continuing offense statute with a new legislative enactment. In 1958 the obscenity statutes were amended to prohibit "use" of the mails, ${ }^{80}$ thus making the mailing of obscenity inescapably a continuing offense by bringing it under the provisions of the second paragraph of section 3237.

The Supreme Court has continued to manifest its discomfort with the multi-venue and continuing offense concept in a variety of cases, and conflicting interpretations of both constitutional and statutory venue provisions have marked the cases decided by the Court since Johnson.

In United States $v$. Anderson, ${ }^{91}$ a selectee had been ordered by his draft board in the Eastern District of the State of Washington to report for induction at Fort Lewis in the Western District of the State. The selectee reported but refused to take the oath unless a vaccination requirement was waived. The Supreme Court held proper venue had been laid where the selectee had refused to submit to induction and not where the order had been issued by the local draft board. In setting down a much-quoted rule, the Court said that where Congress does not specify the place the crime was committed, "the locus delicti must be determined from the nature of the crime alleged and the location of the act or acts constituting it." ${ }^{92}$ Thus, where the crime alleged is

88205 F.2d 619 (10th Cir. 1953).

89 The court pointed out:

The second paragraph of $\$ 3237$ must be read in the light of the Sixth Amendment to the United States Constitution .... We think there is a clear distinction between a deposit for mailing or delivery and the use of the mails. The use of the mails continues from the point of deposit to the point of delivery. Crimes involving the use of the mails are therefore continuing crimes, but the unlawful act defined in $\S 1461$ is the deposit for mailing . . . .

205 F.2d at 621.

90 See note 17 supra, where the text of the statutes, as amended, is set out.

91328 U.S. 699 (1946):

92 Id. at 703. 
the failure to perform a legally required act, there is only one possible venue-the crime is committed at the place fixed for performance of the act. In Anderson, such a rule presented no great difficulties because venue was laid at Fort Lewis where the selectee was physically present. In Johnston $v$. United States, ${ }^{93}$ however, which presented a factual situation similar to that in Anderson except that the defendants had never reported to the specified place, application of the rule resulted in the defendants being removed great distances from their homes to the place of trial. In Johnston, Mr. Justice Reed, this time writing for the majority (Mr. Justice Douglas being joined by Mr. Chief Justice Warren and Mr. Justice Black in dissent), averred that "the possibility that registrants might be ordered to report to points remote from the situs of draft boards neither allows nor requires judicial changes in the law of venue. . . . [P] ublic policy . . . fixes the situs of the trial in the vicinage of the crime rather than the residence of the accused." "94 This extension of the Anderson rationale to a situation where "no act of any kind was committed in the distant district" ${ }^{85}$ was at best questionable, particularly since the Anderson decision had deliberately left open the question whether a different result might have been reached "if appellee had never left Spokane or reported at Fort Lewis." ${ }^{88}$

In United States v. Cores, ${ }^{97}$ an alien seaman had remained in the United States over the time allowed by his conditional landing permit, thus violating the Immigration and Nationality Act. ${ }^{98}$ The defendant had entered the United States in Philadelphia and had been apprehended and indicted in Connecticut. The permit had expired, however, before the defendant had ever reached Connecticut. In interpreting the special venue provision, Mr. Justice Clark for the majority ( $\mathrm{Mr}$. Chief Justice Warren and Justices Black and Douglas once more dissented, on the ground that the offense was not a continuing one) pointed out that "the provision for trial in the vicinity of the crime is a safeguard against the unfairness and hardship involved when an accused is prosecuted in a remote place. Provided its language permits, the act in question should be given that construction which will respect such considerations." 89 The Court then construed the word "remains" in the statute to mean a continuing presence and held that the act had made the offense a continuing one. Certainly as to its effect on this

88351 U.S. 215 (1956).

$94 \mathrm{Id}$. at $220-21$.

95 Id. at 223. The dissenters appear to have tried to bring this offense within the Johnson approach. Thus, they argued that there was room for doubt as to where the crime was committed and such doubts should be resolved in favor of trial at the defendants' residence in the light of underlying constitutional policy.

96328 U.S. at 706.

97356 U.S. 405 (1958).

98 Section 252 (c), 66 Stat. 220 (1952), 8 U.S.C. $\$ 1282$ (c) (1964).

98356 U.S. at 407 . 
particular defendant the result was just, since it meant that he would be tried in Connecticut where he had been apprehended. The Court, indeed, pointed to this as one reason for its holding and also to the fact that by considering the offense a continuing one it made it possible for the defendant in such a case to avail himself of the benefits of Rule 21(b) of the Federal Rules of Criminal Procedure, which allows change of venue upon motion of the defendant in some circumstances. ${ }^{100}$ Finally, the Court warned that a contrary ruling would severely limit the effectiveness of the statute, since in other cases the Government might be faced with an insurmountable problem of proving where the defendant was at the time his permit ran out.

Travis $v$. United States ${ }^{101}$ presented the unusual situation of a criminal defendant arguing for the right to be tried in a distant court. The defendant, a labor union leader, was prosecuted in Colorado for allegedly mailing from Colorado to Washington, D. C. a false noncommunist affidavit required by the Labor Management Relations Act. ${ }^{132}$ The Government claimed that since the illegal act had been begun in Colorado and completed in Washington it could be prosecuted in either place. Mr. Justice Douglas, writing this time for a majority of the Supreme Court, held that venue was proper only in Washington. The Court found that filing of the affidavit was not required but rather was merely a condition precedent to the use by the union of certain National Labor Relations Board procedures of which it could avail itself or not as it chose. Had the filing been a required act, "the whole process of filing, including the use of the mails, might logically be construed to constitute the offense." 103 Since it was not required, the offense was not committed until the actual filing. Mr. Justice Harlan for the dissent (joined by Justices Frankfurter and Clark) argued that "in this kind of case, prosecution in the district in which the affidavit was executed, most often I wotld suppose the place where the union offices are located, is more likely to respect the basic policy of the Sixth Amendment." 104 Certainly the majority gave insufficient

100 FED. R. CRTM. P. 21 (b) :

For the convenience of parties and witnesses, and in the interest of justice, the court upon motion of the defendant may transfer the proceeding as to him or any one or more of the counts thereof to another district.

At the time of the Cores case, the predecessor of this rule limited change of venue, for reasons other than prejudice in the district, to those cases where venue existed in more than one district. Advisory Committee Note following FED. R. CRIMr. P. 21(b). The operation and impact of this rule with respect to prosecutions for the mailing of obscenity are discussed in section III of this Comment.

101364 U.S. 631 (1961).

102 This prosecution was brought under the so-called "false statement statute," 18 U.S.C. \$ 1001 (1964), which was specifically made applicable to the type of affidavit here in question by $\$ 9(\mathrm{~h})$ of the Labor Management Relations Act. 61 Stat. 146 (1947). This section was later repealed by $\$ 201$ (d) of the Labor Management Reporting and Disclosure Act of 1959. 73 Stat. 525.

103364 U.S. at 635.

104 Id. at 640 (dissenting opinion). 
attention to the problem that, although the decision was advantageous to this particular defendant, the likelihood was created that in future prosecutions defendants would be tried in places distant from where they had acted. In any event, the decision may represent an interpretation more restrictive than earlier cases as to what types of offenses may be subsumed under the first paragraph of section 3237(a). ${ }^{105}$ Under this interpretation, where acts are merely preparatory to an offense which may be described as involving a single act element only, the location of which is specified by statute, such preparatory acts will probably not be deemed sufficient to bring the offense under the first paragraph of section 3237 (a). Thus any tendency in the lower federal courts to find such preparatory acts to be a sufficient basis for multivenue may be inhibited. ${ }^{106}$

Whatever may be the implications of the Travis case for the future, the general tendency of the federal courts to view the constitutional venue provisions as tools of interpretation to be called into play only when Congress is silent or ambiguous in its definition of the place of a crime is likely to continue. Since the Constitution requires only that trial be held at the place where the crime is committed, Congress can, without transgressing these constitutional limits, declare the locus delicti to be almost anywhere having even the most minimal contacts with the crime. Provided that the voice of Congress is loud and clear, the courts need not inquire further as to the justification for the venue selected. Any resulting hardship to the defendant goes merely to the wisdom of the legislative policy and not to its constitutionality.

The present judicial tolerance for less restrictive venue provisions may be influenced in part by the fact that defendants have recourse to a motion under Federal Rule of Criminal Procedure 21(b) for change of venue "in the interest of justice." In general, however, the major impetus behind the growing acceptance of such broad venue choice would appear to be the feeling that such provisions are necessary for the efficient administration of justice. Thus they provide a means of relieving overcrowded dockets in some districts by draining off the judicial business to other districts where government prosecutors and courts are less burdened. More important, they are seen as a way of reaching new interstate crimes which otherwise might be difficult to prosecute in the face of archaic procedural rules or constitutional limitations on state jurisdiction. To this extent, the trend to more liberal venue provisions may be viewed as a corollary of the more general trend toward extending federal criminal jurisdiction into areas of misconduct formerly deemed to be state concerns. These con-

105 Abrams 786. This case has been strongly criticized. The Supreme Court 1960 Term, 75 Harv. L. Rev. 40, 190 (1961).

108 See, e.g., United States v. Gross, 276 F.2d 816 (2d Cir.), cert. dènied, 363 U.S. 831 (1960). 
siderations are further reinforced by a reluctance on the part of many courts to allow prosecutions to fail and the guilty to go free merely because of technical errors in the choice of forum.

Because of these substantial factors, the continuing offense concept has become securely engrained in the administration of federal criminal law and the constitutionality of the concept itself, as opposed to its application in a particular area of criminal law, would appear to be no longer open to attack. Unfortunately, however, as may be seen from the foregoing discussion of some recent cases, overly broad court interpretations as to where a crime is committed tend to increase greatly the erratic and arbitrary character of venue in many federal prosecutions. Nor does such encouragement of verbal games truly implement the spirit of the Constitution which its adherents claim to be serving. To a great extent these adverse effects could be avoided were the courts and Congress to reserve use of the continuing offense concept for exceptional situations and were they to employ more limited interpretations of where a crime is actually committed, construing this to be-if at all possible-where a defendant was physically present and acting at the time of the offense. To date neither the Supreme Court nor Congress has shown any such inclination to limit the impact of the continuing offense concept. Rather:

It appears that Congress, by its definition of the elements of offenses, by its formulation of the general venue provision, and by enactment of specific venue provisions attached to particular offenses exercises an almost plenary power over venue. The constitutional venue requirement only fixes some undefined outer limits. ${ }^{107}$

\section{Obscenity and Multi-Venue}

In the preceding section of the Comment it has been shown that the impact of the constitutional provisions has been merely to require that a particular approach, based upon the nature of an offense and of the act or acts constituting it, be used in resolving any issue of venue. The task of the court is to apply this approach in accord with what is perceived to be the underlying constitutional policy; but the court may do so only in those cases where Congress has left the matter in doubt. By using the crime committed formula as an excuse for permitting Congress to define broadly where a crime is committed, the courts have enabled Congress to establish almost nationwide venue for certain offenses, with resultant hardship to defendants who must stand trial far from home. In the area of obscenity prosecutions this hardship is compounded by the vagaries of the law of obscenity itself, which make choice of venue a peculiarly sensitive and critical problem 
for the defendant. In obscenity prosecutions, as in few others, change of venue probably will result in change of verdict.

The constitutionality of the exercise of congressional discretion in excluding objectionable material from the United States mails is well established as part of the larger power vested in Congress to establish post offices and to regulate the entire postal system of the nation. ${ }^{108}$ That obscenity itself is not constitutionally protected by the first amendment is by now equally certain. ${ }^{100}$ The problem was first squarely faced by the Supreme Court in Roth v. United States. ${ }^{110}$ After examining colonial constitutions and statutes making libel and obscenity illegal, Mr. Justice Brennan for the Court stated that

all ideas having even the slightest redeeming social importance .. . have the full protection of the guaranties, unless excludable because they encroach upon the limited area of more important interests. But implicit in the history of the First Amendment is the rejection of obscenity as utterly without redeeming social importance. ${ }^{111}$

The decision then set forth a standard of obscenity which the Court felt would be constitutionally justifiable and which has formed the basis of all other standards since the decision:

whether to the average person, applying contemporary community standards, the dominant theme of the material taken as a whole appeals to prurient interest. The Hicklin test, judging obscenity by the effect of isolated passages upon the most susceptible persons, might well encompass material legitimately treating with sex, and so it must be rejected as unconstitutionally restrictive of the freedom of speech and press. ${ }^{112}$

The Court agreed with the defendants that the terms of section 1461 of the obscenity statute were vague, but stated that "this Court . . . has consistently held that lack of precision is not itself offensive to the requirements of due process. . . . [A]11 that is required is that the language 'conveys sufficiently definite warning as to the proscribed conduct when measured by common understanding and practices , 113

108 See Public Clearing House v. Coyne, 194 U.S. 497 (1904) ; Ex parte Jackson, 96 U.S. 727 (1878).

109 See Ginzburg v. United States, 383 U.S. 463 (1966) ; Jacobellis v. Ohio, 378 U.S. 184 (1964); Manual Enterprises, Inc. v. Day, 370 U.S. 478 (1962); Roth v. United States, 354 U.S. 476 (1957).

110354 U.S. 476 (1957).

111 Id. at 484.

112 Id. at 489. (Emphasis added.)

113 Id. at 491, quoting from United States v. Petrillo, 332 U.S. 1, 8 (1947). 
It was clear even as the decision was handed down that the proposed test raised serious problems as to whose standards were to be applied in judging a particular work. Mr. Chief Justice Warren, in concurring, pointed out that "present laws depend largely upon the effect that the materials may have upon those who receive them. It is manifest that the same object may have a different impact, varying according to the part of the community it reached." 114 Mr. Justice Harlan, dissenting, focused on the problem of differing standards from state to state, finding them to be a source of strength rather than confusion. He saw the real disadvantage inherent in the majority decision to be the "danger of a deadening uniformity which can result from nation-wide federal censorship, and in view of the fact that the constitutionality of this conviction must be weighed against the First and not the Fourteenth Amendment." 115 But the majority opinion gave the courts no guidance as to what the "community" was whose "community standards" were to be applied in determining whether particular material was obscene. ${ }^{116}$ As late as 1960 Lockhart and $\mathrm{McCl}$ ure were asking:

Is it a community bounded by geographical limits or a community formed along cultural lines? If a geographical community, is it the local community in which the censorship of material for obscenity takes place? And if local, how locala particular state, or urban, or rural area? Or is it the national community or even the larger international community called the western world? And if it is the community's contemporary standards that are to be applied, what is to be done with materials like Jonathan Swift's poems to Celia-accepted and widely read in the past-that are likely to be a bit too raw for the contemporary standards of some communities however defined. ${ }^{117}$

Some federal district courts emphatically claimed the right of jurors in their districts to apply their own local standards as they saw fit, ${ }^{118}$ writing off the heavy burden cast upon publishers and distributors of having to know every local standard of an entire nation as one of the hazards of their business.

114354 U.S. at 495 (concurring opinion).

$115 \mathrm{Id}$. at 506-07 (dissenting opinion).

116 The reference to community standards in Roth was not original with that case. Its source is usually attributed to Judge Learned Hand, who, in dictum, said "should not the word 'obscene' be allowed to indicate the present critical point in the compromise between candor and shame at which the community may have arrived here and now?" United States v. Kennerley, 209 Fed. 119, 121 (S.D.N.Y. 1913).

117 Lockhart \& McClure, Censorship of Obscenity: The Developing Constitutional Standards, 45 MinN. L. REv. 5, 49-50 (1960).

118 See, e.g., United States v. Frew, 187 F. Supp. 500 (E.D. Mich. 1960), in which the court denied collateral estoppel effect to earlier district court proceedings 
In 1962, however, the Roth standard was further amplified by the opinion in Manual Enterprises, Inc. v. Day, ${ }^{119}$ where the Court was faced with the problem of an alleged violation of section 1461 by the mailing of magazines intended to appeal to homosexuals. Mr. Justice Harlan, announcing the judgment of the Court in an opinion in which only Mr. Justice Stewart concurred, ${ }^{120}$ after finding the magazines to be lacking in patent offensiveness, went on to discuss the problem of community standards:

There must first be decided the relevant "community" in terms of whose standards of decency the issue must be judged. We think that the proper test under this federal statute, reaching as it does to all parts of the United States whose population reflects many different ethnic and cultural backgrounds, is a national standard of decency. We need not decide whether Congress could constitutionally prescribe a lesser geographical framework for judging this issue which would not have the intolerable consequence of denying some sections of the country access to material, there deemed acceptable, which in others might be considered offensive to prevailing community standards of decency. ${ }^{121}$

The problem of the constitutional necessity for a national standard of obscenity received its most extensive consideration in Jacobellis $v$. Ohio, ${ }^{122}$ where the Court was faced with a violation of a state statute by exhibition of an allegedly obscene movie. Mr. Justice Brennan, announcing the judgment of the Court, reiterated the view that Roth required a national standard. Admitting that local communities in the nation were diverse and might vary in their tolerance of "obscenity," the opinion pointed out that the Court would not sanction a constitutional standard which varied with state, county or town lines:

in Los Angeles in which ostensibly the same materials as those forming the basis of the Michigan prosecution were found to be not obscene. The court pointed out that what the community of Los Angeles may have found not obscene may meet a different standard in Michigan. . . . If by using the Los Angeles proceedings as an irrevocable license and imprimatur, without limit as to time or place, these defendants can send their merchandise wherever they please, then indeed are they the ones who will set the standard for every community they choose as their market.

Id. at 506. But see Flying Eagle Publications v. United States, 273 F.2d 799, 803

(1st Cir. 1960), in which the court pointed out that

while we may assume that a jury would accurately reflect the contemporary standards of the particular community from which it was drawn, we are dealing here with a federal statute having national scope and no doubt community standards differ rather widely over the country at large.

119370 U.S. 478 (1962).

120 There was no majority opinion in Mamual. Mr. Justice Black concurred in the result. A separate concurring opinion by $\mathrm{Mr}$. Justice Brennan was joined in by the Chief Justice and Mr. Justice Douglas. Mr. Justice Clark was the sole dissenter. Two Justices, Frankfurter and White, did not participate.

121370 U.S. at 488.

122378 U.S. 184 (1964). 
[T]o sustain the suppression of a particular book or film in one locality would deter its dissemination in other localities where it might be held not obscene, since sellers and exhibitors would be reluctant to risk criminal conviction in testing the variation between the two places. It would be a hardy person who would sell a book or exhibit a film anywhere in the land after this Court had sustained the judgment of one "community" holding it to be outside the constitutional protection. $^{123}$

As in Manual, however, the opinion announcing the judgment of the Court in Jacobellis was not a majority opinion, and it was joined only by Mr. Justice Goldberg. The remainder of the Court, except for Mr. Justice White, who merely concurred in the judgment, set out the divergent lines of reasoning which were to mark future Supreme Court obscenity decisions. Justices Black and Douglas concurred in the result, but on grounds that under the first amendment all censorship of obscenity is prohibited. ${ }^{124} \mathrm{Mr}$. Justice Stewart propounded the view that only hard core pornography, which he could not define, was without constitutional protection, and, finding the film not to be "hard core," concurred in the result. ${ }^{125}$ It is interesting that, although the Brennan opinion cited with approval the Harlan opinion in Manual, Mr. Justice Harlan was among the dissenters in Jacobellis on the ground that the states are constitutionally permitted a wider latitude in determining what is obscene than is the federal government. ${ }^{126}$ Finally, the dissent of the Chief Justice joined in by Mr. Justice Clark rejected in toto any constitutional necessity for a national standard, alleging that "there is no provable 'national standard' and perhaps there should be none. . . . This Court has not been able to enunciate one, and it would be unreasonable to expect local courts to divine one." 127 Thus, although Jacobellis has become known as the case which established the constitutional necessity for a national standard, this requirement received the support of but two of the Justices, who in future cases would likely be joined by Mr. Justice Harlan only in cases involving federal as opposed to state censorship.

In any event, the gist of the Jacobellis requirement seems to be that the local jury, faced with a particular piece of alleged obscenity, is expected to transcend its own local prejudices and standards and, by some vague alchemy, arrive at a so-called national standard. If the jury can anticipate that the material might be acceptable under a "national standard," the jury is to find the material not obscene, no

123 Id. at 194.

$124 I d$. at 196 (concurring opinion).

125 Id. at 197 (concurring opinion).

$126 \mathrm{Id}$. at 203 (dissenting opinion).

127 Id. at 200 (dissenting opinion). 
matter how patently offensive it might be considered in the community where the jury is sitting. Certainly such an approach requires an almost super-human objectivity on the part of an individual juror. ${ }^{128}$

Granting the dubious legal proposition that the standard of obscenity to be applied must be national, and the even more dubious psychological proposition that juries with proper guidance will be able to rise above their own community prejudices, can we then assume the existence in fact of a uniform national standard which the judge and jury can apply? In view of the great diversity of ethnic and religious viewpoints in America and the present flux and uncertainties regarding mores and social values, the existence of any identifiable national standard would seem to be highly unlikely. The Supreme Court has never directly ruled on the issue of whether evidence of the community standard is required, although Justices Frankfurter (in a concurring opinion) and Harlan (concurring in part and dissenting in part) have suggested that exclusion of such evidence at trial would constitute denial of due process. ${ }^{129}$ Some courts have required proof by the government that the challenged material actually appealed to the prurient interest of the average man. In United States $v$. Klawe, ${ }^{130}$ the Second Circuit pointed out that "the enlarged judicial function in this area requires that we consider the proof or lack thereof and the manner in which the case was placed before the jury, not just whether the material could possibly be brought within the range of the so-called 'obscenity' statute." 131 After finding that the jury had been given no evidence on which to judge the material's prurient appeal, the court remarked that "too easily the jury could aid suppression simply on the basis of speculations and suspicions about the prurient appeal of material to some unknown, undefined person whose psyche is not known. With the First Amendment in the background, this cannot be abided." 132 In the absence of sufficient proof of obscenity, "it would be altogether too easy for any prosecutor to stand before a jury, display the exhibits involved and merely ask in summation: "Would you want your son or daughter to see or read this stuff?' A conviction in every instance would be virtually assured." ${ }^{133}$ Yet, in another obscenity case, ${ }^{134}$ the same year and in the very same court, where all facts had

128 This problem is somewhat alleviated by the enlarged judicial function in the area of obscenity. As indicated by Mr. Justice Brennan in Jacobellis, "since it is only 'obscenity' that is excluded from the constitutional protection, the question whether a particular work is obscene necessarily implicates an issue of constitutional law" and independent review of the facts of each case is essential. Id. at 188.

129 Smith v. California, 361 U.S. 147, 164-65, 171 (1959). See also Comment, 76 HARV. L. REV. 1498 (1963).

130350 F.2d 155 (2d Cir. 1965).

$131 I d$. at 160 .

$132 I d$. at 167 .

$133 I d$. at 170 .

134 United States v. Davis, 353 F.2d 614 (2d Cir. 1965), cert. denied, 384 U.S. 953 (1966). 
been stipulated except whether the material itself was obscene, the majority held that the defendant had also stipulated away the requirement that the government introduce evidence of appeal to prurient interest. Judge Waterman, in dissent, pointed out that the analogy of the jury's function in these cases to that of a jury in a negligence case

was fairly persuasive as long as the jury's decision that certain material was obscene could be viewed as the legal expression of revulsion against the material by the community from which the jury was drawn . . . . But we now know the standard is national, not local. . . . I am not persuaded that, without some evidence other than the records and labels and each juror's own personal reaction thereto, a jury can appraise such material .... ${ }^{\mathbf{1 3 5}}$

Where courts realize that a jury is not well suited to expressing the national standard of obscenity and either scrutinize the material before submitting it to the jury or require evidence as to what the standard is and evidence that the material appeals to prurient interest, there is some protection for the defendant against the subjective speculation of the jury. At least one court, however, while allowing expert testimony, has held that the jury is not bound to accept it, even where the experts are uncontradicted. ${ }^{136}$ And another court, viewing the jury's verdict as, in Learned Hand's terms, "a small bit of legislation ad hoc, like the standard of care," 137 has held that such testimony is not a necessary part of the government's case. ${ }^{138}$

The preceding cases show the great difficulty courts have had in arriving at and applying an appropriate standard against which to measure the obscenity of a particular work. The appeal to "contemporary community standards," if taken as referring to those of particular state or local communities, may be held violative of constitutional guarantees of free speech. Yet, when the standard is taken as referring to the nation as a whole, it proves to be essentially illusory, for no juror can truly stand apart from his own notions of what is obscene or offensive and apply those national standards which as yet have not been satisfactorily defined by any court. As a result, the "guilt or innocence of a defendant charged with obscenity must depend in the final analysis upon the personal judgment and attitudes of particular individuals and the place where the trial is held." 139

135 Id. at 617 (dissenting opinion).

136 Alexander v. United States, 271 F.2d 140 (8th Cir. 1959).

137 United States v. Levine, 83 F.2d 156, 157 (2d Cir. 1936).

$188 \mathrm{Kahm}$ v. United States, 300 F.2d 78 (5th Cir.), cert. denied, 369 U.S. 859 (1962).

189 Ginzburg v. United States, 383 U.S. 463, 480 (1966) (dissenting opinion of Mr. Justice Black). 
It is within this context of conflicting regional standards as to what is or is not obscene that we must judge the propriety of converting the mailing of obscenity into a continuing offense which can be prosecuted not only in any district where mailed or received but also in any district through which the material passes. The present state of obscenity law, if it requires a national standard (as is often uncritically assumed), puts the courts in the curious position of attempting to enforce a statute in terms of a national standard although the statute was passed expressly to enable government prosecutors to take advantage of local standards. This statutory intent becomes apparent from an examination of the legislative history.

As was mentioned earlier in this Comment, ${ }^{140}$ the 1958 amendments to the obscenity statutes had been intended to get around the restrictive venue imposed by the Ross decision. While the House of Representatives wanted from the first to provide for prosecution not only where obscene matter was mailed or received but also in any intervening district, the broad provision ran into some difficulty in the Senate. Rather than accept the House version, the Senate Judiciary Committee, under the leadership of Senator Kefauver, amended the House bill so as to allow prosecution only at the place of mailing or receipt. The Committee made it clear in its report that it considered this to be a reasonable compromise between Ross and the House measure:

The committee adopts this middle view on the ground that unrestricted "forum shopping" can lead to abuses and is, therefore, against public policy. . . . The main evil to be combatted is the harm done to those who are exposed to obscene material at the point of receipt. . . . Thus the main problem is effectively dealt with while public policy against providing too many forums from which to select is satisfied by the elimination of prosecutions in judicial districts through which the nonmailable material passes. . . .

Another public policy deserving of mention is the need to prevent unwarranted Federal encroachment into the criminal field. The test of settling local penal problems locally is still a good test, and it is believed that this bill meets it. ${ }^{141}$

Published along with the report was a May 17, 1957, letter from the General Counsel of the Post Office to Emanuel Celler, chairman of the House Judiciary Committee, discussing the Ross decision and explaining that "the importance of this decision rests in the fact that it is sometimes difficult to obtain a conviction for the mailing of obscene

140 See text accompanying notes $89-90$ supra.

141 S. REP. No. 1839, 85th Cong., $2 d$ Sess. 3 (1958). 
matter in certain jurisdictions." 142 The Senate insisted upon its amendments, and Patrick Hillings, a member of the House Judiciary Committee and a House conferee on the bill, claimed on the floor of the House that the Senate had "torpedoed" the bill:

Mr. Speaker, the question of venue usually seems to be somewhat of an esoteric legal matter about which laymen are confused. . . . [V] ]enue is a question of neighborhood-the neighborhood in which a crime is alleged to have been committed, and is therefore to be prosecuted. . . . [A]s H.R. 6239 was torpedoed in the Senate, the broadened venue provision is absent. If insufficient evidence could be gathered to support a prosecution in the Federal district of mailing or receipt, or if an overworked grand jury could not attend to the matter in time, or if for any other reason an indictment and prosecution could not be speedily secured in one of those Federal districts, the smut dealer would be perfectly free to continue his operations, notwithstanding that other evidence in another Federal district might be readily available to support an indictment and prosecution. ${ }^{143}$

In conference the Senate members agreed to accept the House version. The Conference Report is particularly interesting for the way it dealt with the original Senate concerns over forum-shopping:

Question has been raised as to whether the Post Office Department intends to press for the prosecution of violations of the law in the jurisdictions through which the unlawfully mailed matter passes in transit, if the language of the House of Representatives is restored to the bill by the conferees. In a letter dated August 5, 1958 and addressed to the chairman of the House Committee on the Judiciary, the General Counsel of the Post Office Department, Mr. Herbert B. Warburton stated that the Post Office Department answers this question "emphatically" in the negative. ${ }^{144}$

It is difficult to understand why Congress and the Post Office would fight for inclusion in the statute of intervening district venue if their intent was that this provision not be utilized. Despite the Post Office Department's assurances that intervening district venue would not be used, it is clear that, by providing for such venue in addition to venue in the districts of mailing and receipt, the legislative intent was to facilitate more successful prosecutions for mailing obscenity by

$142 I d$. at 4.

143104 CoNg. REC. 15610-11 (1958).

144 H.R. REP. No. 2624, 85th Cong., $2 d$ Sess. 4 (1958). 
allowing government prosecutors the widest possible venue alternatives in order that they might be able to bring criminal proceedings in areas where sympathetic juries could be expected. ${ }^{145}$ Nor is this conclusion negatived by the fact that no prosecution has apparently yet been brought in an intervening district alleging violation of the obscenity laws.

It is, of course, impossible, except perhaps by extensive research involving great expenditures of time and money, to prove the effect which the existence of laws such as this has upon authors, publishers and distributors of books. One cannot point to the book refused publication, to the book never ordered by a distant bookstore or to the book refused distribution because "doubtful." If the impact of these laws were to be limited to so-called hard core pornography, and if it could be shown that the standard likely to be applied to such material would vary only slightly from community to community, such restraints on the free dissemination of written works might be justifiable because de minimis. In the light of the decisions discussed above, however, it becomes clear that such hard core pornography will be only a part of that body of works which will fall under the ban of the censor, and that hard core pornography is no easier to define than any other kind. In addition, a work not inherently obscene in itself may prove to be so solely by virtue of provocative, though not inherently obscene, merchandising and advertising. ${ }^{146}$ Surely then the lack of certainty as to the standard of obscenity, procedural rules designed to take advantage of local prejudices and sectional provincialism and, above all, the ever constant threat that a dubious or borderline work may subject one to multiple prosecutions in distant jurisdictions for each act of mailing, cannot fail to exert a repressive effect on free speech and press in the United States.

The inevitable tendency is to make the serious author timid, to cramp his mind so that the books he is not afraid to write will fall far below the level of his abilities. And society, as a consequence of the anxiety to suppress smut at all costs, may lose the values of important literary, scientific, and educational contributions. ${ }^{147}$

Some courts ${ }^{148}$ have attempted to justify the extension of the continuing offense doctrine into new areas of criminal law on grounds

145 See Hearings on Control of Obscene Material Before Subcommittee on Constitutional Amendments ard Subcommittee To Investigate Juvenile Delinquency of the Senate Committee on the Judiciary, 86th Cong., 1st \& 2d Sess. 16-18 (1960). See also Staff of Subcommitree on Postal Operations, House Committee on Post Office and Civir Service, 86TH Cong., 1st Sess., Report on Obscene Matter Sent Through the MaIL 7 (Comm. Print 1959).

146 See Ginzburg v. United States, 383 U.S. 463 (1966).

147 Lockhart \& McClure, Literature, The Law of Obscenity and The Constitution, 38 MinN. L. REv. 295, 373 (1954).

148 United States v. Cores; 356 U.S. 405,410 (1958); United States .v. Cashin, 281 F.2d 669, 675 (2d Cir. 1960). 
that the dangers inherent in the doctrine have been ameliorated by the promulgation of Federal Rule of Criminal Procedure 21(b), which provides for change of venue when, in the discretion of the judge, such a change would be in the interest of justice. Because of the large discretionary element, however, this rule has proved less of a safeguard than might be anticipated. In many obscenity cases courts have construed the rule in such a way as to rob it of any protective value for the defendant. In United States $v$. West Coast Neres Co. ${ }^{148}$ the California defendants had been indicted in Michigan for mailing obscene materials. The defendants' Los Angeles attorney moved under Rule 21 (b) to transfer the case to the Southern District of California on grounds of physical and financial hardship and the possibility of being subjected to multiple prosecutions on the basis of differing community standards. The motion was refused as not being in the interests of justice. Although the court stressed the right of a Michigan jury to apply local standards, the court also held that, while undoubtedly the defendants, their attorneys and their witnesses would be inconvenienced by having to travel to Michigan, the government witnesses would be equally inconvenienced were the trial transferred to California. Since there was no district convenient for all, there was no need to transfer the proceedings. This ruling was challenged by the defendants the following year ${ }^{150}$ when a new motion was made for a change of venue based on the facts that in the interim period the Manual decision had made the appropriate standard of obscenity a national standard and that one defendant had since suffered a heart attack. Once again the transfer was not found to be in the interest of justice. The court reiterated the importance that a Michigan jury have the opportunity to pass on the material in question and indicated its approval of Toscano $v$. Olesen, in which another court had said, "we need not concern ourselves with the possible hardship resulting from the exercise of this power. For that affects policy. Our function is merely to give effect to it." 151

The defendants in United States $v$. Luros ${ }^{152}$ were Californians indicted in Iowa for conspiracy to violate the obscenity statutes and for allegedly sending obscene materials into Iowa from Hollywood. It is interesting to note that the very materials alleged to be obscene in the Iowa proceedings had already been held not to be obscene in prior proceedings in the California state courts. The defendants moved for change of venue under Rule 21 (b) on grounds that going to trial in Iowa would prevent them from meeting business and family re-

14930 F.R.D. 13 (W.D. Mich. 1962).

160 United States v. West Coast News Co., 216 F. Supp. 911 (W.D. Mich. 1963). 151 Toscano v. Olesen, 184 F. Supp. 296, 297 (S.D. Cal. 1960). (Emphasis in original.)

152243 F. Supp. 160 (N.D. Iowa), cert. denied, 382 U.S. 956 (1965). 
sponsibilities, would physically and financially tax their resources by requiring transportation of witnesses and attorneys to Iowa and would require a considerable outlay for living expenses during the trial. The court held:

The defendants are in effect, advocating a prosecutive policy which would compel local residents to wait for relief until some United States Attorney in another district saw fit to act. . . . To do so, would deny the residents of this district the lawful means to protect themselves from local distributions of obscene materials. It would mark a partial return to the prosecutive limitations which existed under the now discredited decision in United States v. Ross. ${ }^{153}$

The court found the legislative intent behind making the alleged crimes continuing to be that of allowing local juries to rule on offensive material and that "the strength of this congressional feeling is indicated by Congress' willingness to override the important policy considerations behind Rule 21(b)." 154

Despite this court's weak disclaimers elsewhere in the opinion, the effect of its decision and reasoning is essentially to render Rule 21(b) inapplicable in cases in which there is a clear statutory grant of venue by Congress which takes precedence over the discretionary power of a district court to transfer the case in the interest of justice. There is some authority the other way. Thus, in. United States $v$. Olen, ${ }^{155}$ a New York district court, in a case involving alleged violations of the Securities Act of $1933,{ }^{158}$ was faced with a Rule 21 (b) motion to transfer the trial to Alabama. The company involved had its home office and books in Alabama, the prospectus had been mailed in Alabama and the defendants and most witnesses resided in Alabama. The court in ruling on the motion held that under the rationale of Johnson, a criminal statute had to be construed, if possible, so as to lay venue at the home of the defendant:

I am not unaware of the fact that when former 28 U.S.C. $\S 103$ was incorporated in revised Title 18 U.S.C. in 1948 as Section 3237 . . . it was amended to "meet the situation created by" United States v. Johnson. However, the amendment does not at all act to restrict but rather to broaden the number of jurisdictions in which a criminal trial may be had in the case of continuing offenses. ${ }^{157}$

153 Id. at 176. The reference to "prosecutive limitations" is to the Ross court's decision that venue could properly be laid only in the place of mailing. See note 89 supra and accompanying text.

154243 F. Supp. at 176.

185183 F. Supp. 212 (S.D.N.Y. 1960).

15848 Stat. 74, as amended, 15 U.S.C. \$\$77a-77aa (1964).

157183 F. Supp. at 217 n.4. 
The court then went on to find that the crimes had been "begun" in Alabama so as to fall within the first paragraph of section 3237 and granted the transfer.

Within recent months Rule 21 (b) has been amended so as to increase its flexibility and usefulness. Under the new rule, where convenience of the parties and the witnesses and the interest of justice would best be served by trial in a district in which no part of the offense was committed, transfer to such district may be ordered. ${ }^{158}$ But it should be emphasized again that the rule is discretionary, and refusals of transfer are subject to only narrow review as to abuse of discretion of the court, ${ }^{169}$ and reviewable on mandamus only in extraordinary circumstances. ${ }^{160}$ Some courts, such as Cores, have argued that the greater the number of possible places of venue the more likely it is that the defendant will find a convenient forum to which he can transfer his case. This argument is based on erroneous assumptions as to the availability of transfer and the adequacy of the transfer provisions. Particularly in obscenity cases, the emphasis on community standards has encouraged local courts to retain cases which in less emotionally tinged areas of the law might be granted transfer. Certainly, unless transfer can be easily obtained, the only effect of loose interpretations of venue provisions will be to provide the government with a very broad choice of forums. And, "conceivably Rule 21 (b), which was obviously designed to afford greater protection to defendants, may in practice merely provide an excuse for venue constructions which hold a great potential for abuse by the government." ${ }^{161}$ The tendency for courts to retain control of these cases may also be increased by the recent Supreme Court decision in Platt $v$. Minnesota Mining \& $M f g . C{ }^{162}$ The Court, holding that the court of appeals in ordering transfer under Rule 21(b) had improperly usurped a district court function, reiterated that there was no constitutional right to trial in a defendant's home district and that proper determination of where the crime was committed was essential to lay venue. ${ }^{163}$ It may be significant, however, that this case involved a corporate defendant.

158 Under the old Rule 21 (b) some courts had held that all counts of a multi-count indictment had to be transferable or change of vente could not be ordered. Thus a prosecutor needed only to include in the indictment a single count having venue only in the preferred district to prevent transfer of all other counts. But see United States v. Choate, 276 F.2d 724 ( 5 th Cir. 1960), holding that each count in a multi-count indictment is severable and may be transferred independently of any other to the district where the offense was allegedly committed.

158 See Platt v. Minnesota Mining \& Mfg. Co., 376 U.S. 240, 245 (1964).

160 United States v. Cashin, 281 F.2d 669, 671 (2d Cir. 1960).

161 Abrams 818.

162376 U.S. 240 (1964) (violation of Sherman Act).

163 The fact that Minnesota is the main office or "home" of the respondent has no independent significance in determining whether transfer to that district would be "in the interest of justice," although it may be considered with reference to such factors as the convenience of records, officers, personnel and counsel.

Id. at 245 . 
In view of the difficulty a defendant in an obscenity case faces in obtaining a change of venue under Rule 21 (b) and the likelihood that a jury will apply local standards in judging the obscenity of the materials being questioned, it might be thought that the defendant's best recourse would be to waive jury trial altogether. Under Rule 23 of the Federal Rules of Criminal Procedure, however, jury trial can be waived only with the approval of both the court and the government prosecutor. The constitutionality of this requirement has recently been upheld, ${ }^{164}$ the only limitation apparently being that the prosecution is under a duty not to withhold consent arbitrarily. The government, therefore, could make particularly effective use of this rule, after selecting a venue distant from the defendant's home or place of business, by refusing to consent to waiver of jury and then using its peremptory challenges to remove the more educated and literate jurors. ${ }^{165}$

Another potential source of governmental abuse of its venue powers may result from combining the inherently broad venue possibilities of conspiracy (based on where an overt act takes place ${ }^{168}$ ) with the intervening district venue possibilities of the obscenity cases, although no such cases have been discovered. In most cases the effect of joining a count charging a substantive offense with conspiracy charges is to limit the venue possibilities open to the prosecution. By combining a continuing mailing offense with conspiracy charges, however, venue over the conspiracy could conceivably be extended to any place through which the mail passed on the theory that the mailing was an overt act in furtherance of the conspiracy.

It should be apparent from the foregoing discussion that the government prosecutor in any indictment for the mailing of obscenity possesses tremendous discretionary power to decide where the prosecution will be brought and, thereby, to decide which standards of obscenity will be applied. The defendant may, consistently with section 3237 , be brought to trial not only where he physically placed the questionable material in the mails (the district of deposit), or the destination to which the material was sent and where it presumably had its adverse effect (the district of receipt), but also any district between that of deposit and receipt through which the mail might happen to pass (although such intervening districts do not seem to have been used as yet by government prosecutors). One writer has estimated that a truck travelling or a letter mailed from Los Angeles to New

164 Singer v. United States, 380 U.S. 24 (1965).

165 See Lockhart \& McClure, Censorship of Obscenity: The Developing Constitutional Standards, 45 MINN. L. REv. 5, 110 n.597 (1960), for a suggestion by defense counsel in Alexander v. United States, 271 F.2d 140 (8th Cir. 1959), that these trial tactics were used in that prosecution by the United States Attorney.

16B The government might successfully be able to prosecute for conspiracy recipients of obscene material for private consumption-even though receipt of obscene materials for private use has been held not to violate $\S 1461$. United States v. Sidelko, 248 F. Supp. 813 (M.D. Pa. 1965). 
York City might pass through more than one dozen federal judicial districts. ${ }^{187}$ Conceivably, then, a publisher, distributor or author of allegedly obscene material might be faced with a trial in any one of those more than twelve intervening districts, in which the same printed material might be subjected to twelve different appraisals as to whether it offends the national standard. Nor is that all. Since each act of mailing is a separate offense, the mailer may be subjected to multiple indictments for very similar material with the possibly incongruous result that one mailing would result in conviction but another mailing to another part of the country would not. It is difficult to believe that this potentially nationwide venue which essentially makes the United States one giant federal district is at all consonant with traditional notions of fair play or more importantly with the intent of the framers of the Constitution to protect all criminal defendants from the undue physical and financial hardship and possible emotional intimidation inherent in transportation to distant places for trial. If such a system has little justification even in the ordinary criminal trial, how much less must be the legitimacy of extending this potentially repressive legislation into the area of first amendment freedoms of speech and press. Taken together with the hardship of trial far from home, the fear of conflicting and unpredictable verdicts based on government exploitation of local prejudices can have no other effect but to restrict free expression. Nor will it be only the purveyor of hard core pornography who is made cautious; the serious book vendor and the artist, faced with their inability to predict local reaction to particular works in a time of rapidly changing public mores and customs, will be forced to choose between the integrity of their art and business and the risk of financial and reputational ruin. The Supreme Court has distinguished in the past those legal devices which might be consistent with constitutional guarantees in most applications, but which could not be applied in settings where they had "the collateral effect of inhibiting freedom of expression by making the individual more reluctant to exercise it." 188 A man, the Court continued, "may the less be required to act at his peril here, because the free dissemination of ideas may be the loser." ${ }^{169}$ Certainly such a description might fairly be said to characterize the continuing offense concept as it affects the obscenity statutes.

What is being questioned here is not the power of Congress to regulate what shall constitute nonmailable matter but rather the necessity that the government use such power in a manner consonant with the more important constitutional guarantees set down in the first and sixth amendments. In the words of Mr. Justice Brandeis, "the postal power, like all its other powers, is subject to the limitations of the

187 Abrams 794-95.

168 Smith v. California, 361 U.S. 147, 151 (1959).

160 Ibid. 
Bill of Rights. . . . Congress may not through its postal power put limitations upon the freedom of the press which directly attempted would be unconstitutional." 170

By transforming the mailing of obscenity into a continuing offense, thus allowing prosecution at places other than where the mail was deposited, Congress has bestowed upon the government prosecutor wider powers than are necessary for dealing with the evil to be attacked. It is not sufficient justification for allowing prosecution at the point of delivery that local juries have the right to apply standards more restrictive than those deemed proper by their more sophisticated countrymen. It may, of course, be argued that venue at the place of delivery, as opposed to venue laid in an intervening district, is desirable on the ground that this is where the obscene material has its impact and where the defendant is perpetrating the harm that society seeks to prevent. If, however, this local concern is implemented by use of local standards to judge the material in question, then trial in the place of delivery will both deprive a defendant of the protections of the sixth amendment and transgress constitutional provisions for free speech. If, on the other hand, the standards intended to be used are national, then the interests of the local area where the material was received can just as well be served by having a jury in the area where the material was mailed apply the very same standard in judging its obscenity. This alternative will at the same time accord the defendant the full protection and freedom from hardship guaranteed by the sixth amendment.

Even less justifiable than allowing venue to be laidain the place of delivery is that provision which allows for prosecution in any state through which the obscenity may have passed in the course of mailing. The obscene matter has had no impact in such jurisdictions nor has the disseminator purposely availed himself of doing business in that state or intentionally intruded himself in any way. It is no answer to this complaint that the "gist" of the offense is the use of the mails and so prosecution is proper wherever the mails are used. The essence of the offense is disseminating obscenity, and the purpose of the statute is not to protect the integrity or sanctity of the United States mails per se but to stop the flow of material deemed harmful to national standards of decency. Lastly, it is no justification for granting the government the power to prosecute in intervening districts that the government has as yet exercised this power only infrequently in other areas and not at all in obscenity cases. For whether this dearth of cases is attributable to commendable restraint by government prosecutors, or, as is more likely, to fear that free use of the power will result in judicial reappraisal of its propriety, the power still existsa potential club ready for use in unusual cases-no less chilling in its effect on free speech for being unused.

170 Milwaukee Publishing Co. v. Burleson, 255 U.S. 407; 430-31. (1921) (dissenting opinion). 